$$
\mathfrak{M}
$$




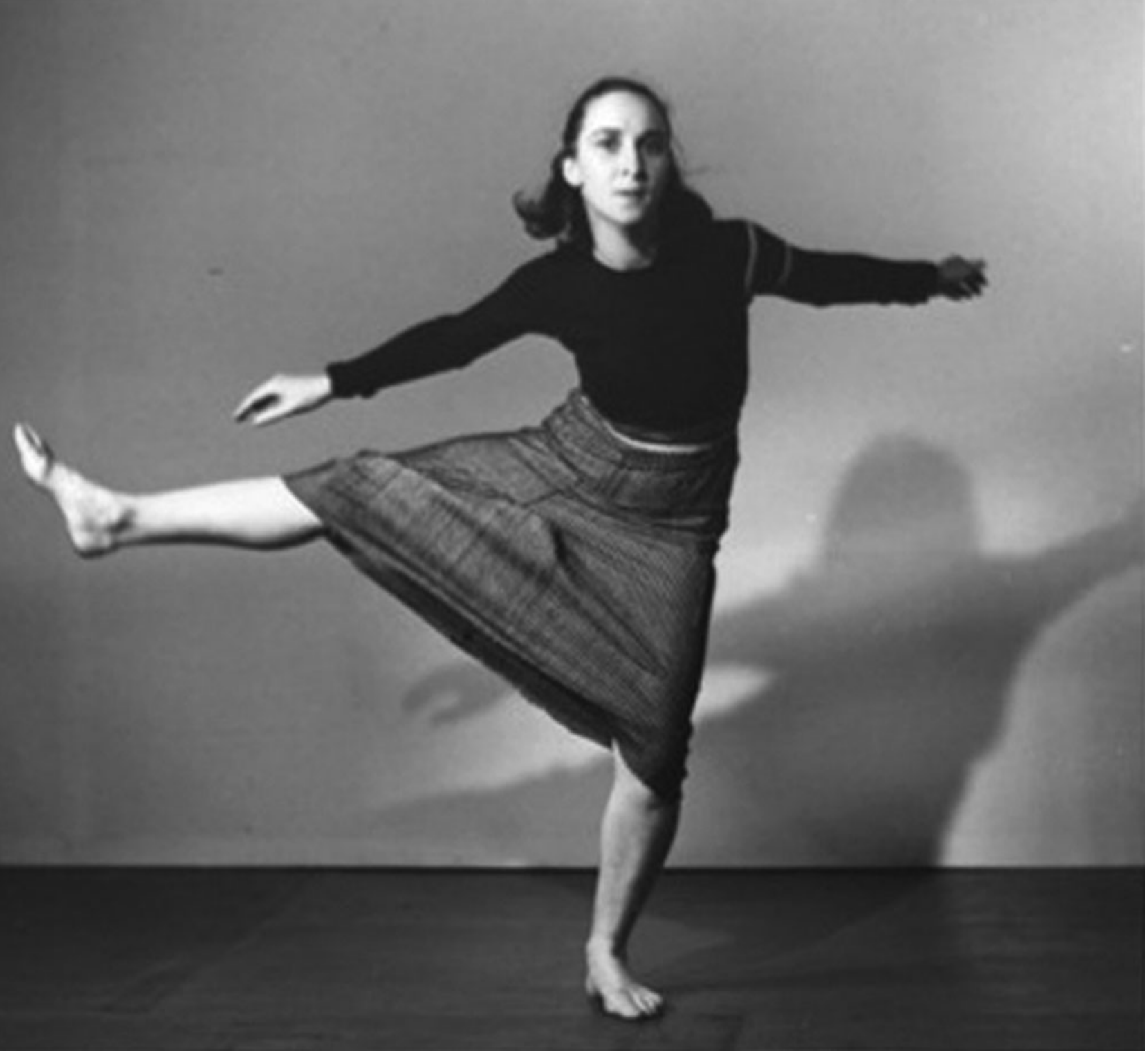




\title{
Inevitable Designs: Embodied Ideology in Anna Sokolow's Proletarian Dances
}

\author{
Hannah Kosstrin
}

\begin{abstract}
nna Sokolow's choreography in Strange American Funeral (1935) and Case History No.(1937) created what New Masses dance critic Stanley Burnshaw (1936) described as inevitable designs: it inscribed indelible etchings in space that spoke truth to power through 1 proletarian ideology. The themes of these dances resonated with Depression-era
\end{abstract} New York leftist audiences aligned with socialist, Communist, and working-class ideals, while Sokolow's melding of form and content answered the prescripts of both revolutionary and modern dance. Reviewers' detailed descriptions of the pieces-in publications including the leftist New Masses, Daily Worker, and New Theatre; the broad-based New York Times and Boston Herald; and Louis Horst's dance-specific Dance Observer-make clear that the work's politics resonated with working-class audiences while its modernist aesthetic similarly attracted a wide range of concert dance-goers. This acclaim afforded Sokolow (1910-2000)—a young, working-class, left-wing Jewish choreographer-the freedom to move among political and artistic circles that a single label of either "revolutionary" or "modern" would have denied her. Her ability to thus cross critical divides speaks to her larger ability to navigate between working-class and elite representative spheres, and between being marked as a revolutionary Jewish Communist and being otherwise unmarked as a universal modern dance choreographer. ${ }^{1}$

Through her portrayal of bodies that were not specifically gendered male or female, her biting commentary, her reputation in performance as a Martha Graham soloist, and in leadership as a Workers Dance League founder, Sokolow transgressed established structures and became a voice of the leftist dance movement. The reception of Sokolow's work, and its discernible traces in photographs, reviews, and dancers' memories, evidences this prominence. As Susan Manning has shown, spectators view a performance in relation to their own social positioning, and engage in "cross-viewing" when "[catching] glimpses of subjectivities from social locations that differ from their own" (2004, xvi). Manning and Susan Leigh Foster have further demonstrated that various aspects of performance production, from venue to genre to critical reception, also contextualize or frame a

Hannah Kosstrin is visiting assistant professor of dance at Reed College, where she teaches courses in dance studies, Labanotation, and contemporary technique. Her manuscript project examines questions of politics and identity relating to Jewishness and gender in Anna Sokolow's choreography. Her articles have appeared in Art Criticism and The International Journal of Screendance, with work forthcoming in Dance on Its Own Terms: Histories and Methodologies, edited by Karen Eliot and Melanie Bales (Oxford University Press, 2013). She was awarded a 2009 Selma Jeanne Cohen Award from Society of Dance History Scholars for her paper, "Of Dreams and Prayers: Topographies of Anna Sokolow's Holocaust Work During and After World War II.” Kosstrin serves as treasurer-elect for the Congress on Research in Dance and is on the Dance Notation Bureau Professional Advisory Committee. She holds a Ph.D. in dance studies from The Ohio State University with a minor in women's history. 
performance (Foster 1986, 59-65; Manning 2004, xviii-xix). During the 1930s, as Manning details, audiences and critics attending and reviewing dance on the concert stage represented a wide spectrum of political, aesthetic, raced, and gendered subjectivities. Sokolow's 1930s critical reception and varied performance venues thus reveal how her work spoke to a hybrid audience. Had Sokolow's content appeared as too bourgeois or not fully proletarian, the leftists would have rejected her. Conversely, if her work had not subscribed to modernist compositional norms, the then-emerging modern dance establishment would have ignored her. It is because Sokolow successfully negotiated a space for herself between these interests that she garnered recognition not only within the New York dance scene, but also internationally by attracting the attention of the postrevolutionary socialist Mexican government.

While Sokolow drew this focus by exposing the plight of the working class through choreographic representations of oppressive authoritarian power or the neglected poor, her refusal to offer solutions to these problems engenders broader implications than if her work was simply dogmatic. In a 1967 interview, Sokolow explained her practice, expounding, "I never gave an answer to what I did. They used to say 'you must finish it' and I would say 'well, who knows what the finish is?' I still don't finish anything because I don't feel that anything ever ends" (quoted in "Talking to Dance and Dancers" 1967, 18). Yet, critic Clive Barnes' 1968 bestowal upon Sokolow of the moniker "prophet of doom" is as apt in the 1930s as the 1960s (54). With choreography perceived as universal but also open-ended, Sokolow's work has a foretelling quality while remaining rooted in the present's urgency and her characters' real-ness. Performed by the ten women of Sokolow's Dance Unit, Strange American Funeral portrayed the gruesome death of an immigrant steel worker who fell into a vat of molten ore after a guardrail failed. ${ }^{2}$ Through dancers' movements that displayed the community's experience of loss, anger, and chaos by their progression in and out of geometric formations, the dance exposed workplace safety violations and illustrated the plight of the working class. Later, translating indictment of societal instability into a solo in Case History No.-, Sokolow used the abstraction from her training with Martha Graham to transcend her own female body to represent crime-committing male youth neglected by society. Taken together, Strange American Funeral and Case History No.- allow for an understanding of how Sokolow's multivalent dancing body - a radical body, a Jewish body, a female body, a modern (dance) body_played a significant role in her ability to navigate critical, political, and gender boundaries with her revolutionary work.

Sokolow was one of many choreographers making these kinds of dances in the 1930s. In a field where groups of bodies made collective proletarian statements, Sokolow instead told individual stories that carried a larger import and hit with a comparatively stronger impact. In Strange American Funeral, the story of one worker's wrongful death is enough to stir a community to action; in Case History No.-, one youth's experience indicates a systemic societal problem. As Mark Franko argues, revolutionary dance was central to the social and political goals of the Left due to its codependence with Communist ideology and its organization of bodies laboring in space and time for proletarian rights against the background of workers on the Fordist assembly line (2002, 1-17). Furthermore, Franko asserts, the emotionalism heightened in these dances-and essential in political bodies as a conveyor of content-outweighed the form/content binary in terms of significance that played out in the pages of many 1930s dance reviews. Though I argue that Sokolow's fusing of form and content in her choreography is what gained her notable success across critical divides in the U.S. and also attracted Mexican artists, intellectuals, and government officials to her work, her nonlinear narratives and open-ended storytelling that demand the viewer's engagement to complete the action onstage make her dances compelling. By thus enlivening the space between the performers and the spectators, moreover, Sokolow's choreography exemplifies the action of bridging dance and politics that Foster (2003) and Randy Martin (1998) have argued are necessary for embodying political theories in order to have a social impact. ${ }^{3}$

Many dance historical narratives omit the specifics of Communism in Sokolow's 1930s work in favor of discussing her more abstracted mid-century choreographies such as Lyric Suite (1953), 
Rooms (1954), and even the Holocaust works Dreams (1961) and Steps of Silence (1967). Indeed, in asserting that the revolutionary dance movement was largely written out of history, Manning notes that dancers like Sokolow "were remembered more for their humanist credentials than for their leftist commitments" (1993, 266). Scholarship until this point has downplayed or denied the Communist connection in Sokolow's life, and understandably so in the aftermath of the Second Red Scare. In this essay, I re-examine how Sokolow's Communist affiliations not only importantly informed her work, but also how these associations connect Sokolow to larger historical international Communist circles in the U.S. and in Mexico. Through reinforcing how central Sokolow's voice was to the larger workers' and Communist movements outside the dance community, my analyses of Strange American Funeral and Case History No. - complicate narratives established during the Cold War that Sokolow's work was not political or that she merely reacted emotionally to the status quo. ${ }^{4}$

\section{Sokolow's Relationship to the Politics of Modern Dance and Revolutionary Dance}

Sokolow was one of many Jewish women, as Julia Foulkes (2000) has detailed, who trained and performed with Martha Graham or Doris Humphrey while running her own revolutionary dance group. These women associated themselves with Communism and socialism to varying degrees. Yet, in the mid-1930s, Sokolow was one of the few choreographers who writers bolstered from many critical or political standpoints. Between the categories of modern and revolutionary dance, critics privileged the technical values of modern dance even-and especially-in dance with socially political content.

Sokolow's views reflected the Socialist and Communist loyalties of the immigrant and largely working-class Eastern European Jewish community from which she hailed. A child of Russian Jewish immigrants, Sokolow grew up in the lower- and working-class neighborhood of New York City's Lower East Side. Sokolow's mother, a garment worker and union organizer, moved Sokolow and two of her three siblings to the Upper East Side when Sokolow's father died of Parkinson's disease. Sokolow began dancing in afternoon classes at the Emmanuel Sisterhood of Personal Service on East 82nd Street in 1919, and in 1925 transferred to the Lower East Side's Henry Street Settlement and Neighborhood Playhouse, where Martha Graham, Louis Horst, Doris Humphrey, Blanche Talmud, and Charles Weidman were on faculty (Warren 1991, 3-16). After training with Graham and Horst at Henry Street, Sokolow joined Graham's company and gained soloist status early in her performing career with Graham, which spanned from 19301939. Horst remained Sokolow's lifelong mentor. Critics often highlighted Sokolow's strong and compelling performances in Graham's work: In 1935, Edna Ocko wrote in New Theatre that Sokolow's "hex dance" duet with Anita Alvarez in Panorama provided "some of the finest dancing of the evening" (27), while in 1937 John Martin noted in The New York Times that Sokolow performed Four Casual Developments "with delightful comedy and skill" (16). These reviews gave Sokolow credibility that carried into her own choreographic career.

Sokolow's Graham lineage provided her with a kind of critical preapproval. Critic William T. Chase, Jr. opined in The Boston Herald that a dancer's training with Graham or Humphrey-Weidman "practically assured one of a certain competence of technique" $(1936,14)$. Sokolow's status as a Graham dancer, moreover, gave her a heightened, even whitened, status as a modern dancer that revolutionary Jewish dancers who did not dance for one of the Big Four-Martha Graham, Doris Humphrey, Charles Weidman, and Hanya Holm-could not claim. ${ }^{5}$ As Rebecca Rossen demonstrates, working-class Jewish dancers such as Sokolow and Sophie Maslow "managed to strategically use the aesthetics of modern dance to Americanize their Jewish bodies" (2011, 339). Thus, even though Sokolow's proletarian choreography embodied her working-class and Jewish identity, 
her Graham training afforded her the privilege of performing as the universal, "culturally unmarked" body that Susan Manning defines as part of whiteness in concert dance $(2007,54)$.

Yet, this lineage, and wide-reaching critical praise, complicates Sokolow's representation in dances such as Strange American Funeral and Case History No.- - While such attention and training arguably align Sokolow with an elite whiteness, it is a different position than some of her leftist contemporaries who in the 1930s and 1940s utilized the transcendence of this whiteness and mapped black experience through their female bodies as a way to align themselves with the plight of oppressed peoples (see Manning 2004, 63). Manning terms this convention "metaphorical minstrelsy," wherein white dancers performed nonwhite themes as universal, while critics like Martin criticized black dancers presenting the same themes for the specificity of the material $(2004,10,35)$. Manning asserts that the performance of Helen Tamiris, a leftist Jewish choreographer whose Negro Spirituals cycle (1928-1944) earned her widespread recognition, "renders the white female body a vehicle for circulating multiple identities" $(2004,12)$. It is worth noting that Jews in the U.S. were not fully considered white until after World War II, thus making this kind of identity circulation through whiteness a mode of assimilation (see Jacobson 1998 and Brodkin 2000). While Sokolow did not directly engage themes of African American struggle, she relied on jazz musical scores in much of her work to create an urban atmosphere (quoted in Battey 1967). As white and Jewish choreographers capitalized on the universalism that modern dance and their gender afforded them to make generalized statements about oppression, Sokolow fit uneasily into these categories where her proletarian dances represented struggles that resonated with her own experience, instead of generalized experience from a social or ethnic position that differed from her own.

Sokolow transformed her years of training and performing with Graham into a powerful performance form that referenced elements of Graham's movement while breaking thematically from Graham's archetypal and heavily Protestant subjects. Dance photographs, posed and in motion, of Sokolow in the 1930s and 1940s show a strong influence of Graham technique in her movement. This aesthetic visually manifests in actions originated in small and large torso contractions, as in photographs of Sokolow's group in Anti-War Trilogy (1935) or Façade-Esposizione Italiana (1937), or in a prominent spiral through the back, as in a photograph of Sokolow posing or improvising, that affects the positions and actions of Sokolow's and her dancers' heads, limbs, and torsos. ${ }^{6}$ Though Sokolow utilized these codified technical elements, she became known for biting irony and satiric wit in her choreography. In "The Revolutionary Dance," a 1936 lecture she gave as part of John Martin's series at the New School for Social Research, Sokolow used the word "revolutionary" to address her impulse to break from existing forms, and to connect her work to the proletariat: "Those working in the revolutionary dance movement place another meaning to the term: that of a movement which allies itself with the point of view of the revolutionary class itself-which, today, is the working class" (quoted in Church 1937a, 27). It is this sentiment that not only highlighted Sokolow among her leftist U.S. contemporaries, but also excited proletarian audiences in Mexico City, which boasted socialist circles that U.S. leftists closely followed. ${ }^{7}$

Revolutionary dance was ideally a marriage of Marxist ideology with professional dance training, wherein dancers embodied proletarian ideals. The onstage challenge for revolutionary choreographers in myriad venues, as Manning notes, was to present dances that both answered concert dance aesthetic demands while remaining "legible" to audiences of workers in union halls (2004, 63). Historians and 1930s contemporary critics interchange the terms "radical," "leftist," and "revolutionary" to denote dancers associated with the Workers (later New) Dance League (WDL/NDL), New Dance Group (NDG), or other 1930s Communist-inspired causes that in one way or another made dances of the proletariat for social change. ${ }^{8}$ While the WDL was an umbrella organization that supported independent leftist dancers and their companies, the NDG was a smaller collection of leftist dancers and independent choreographers who shared a studio space and wanted to bring dance to the masses through affordable classes and low concert ticket prices. Revolutionary dancers, as Stacey Prickett notes, "set out to develop a dance form appropriate to the expression of the 
workers' struggle," where "[ $\mathrm{t}]$ echnique was viewed as a means to an end and not considered as an end in itself" (1990, 55).

Ellen Graff defines two ideological differences prior to 1934 between leftist dancers and so-called "bourgeois" dancers. "Bourgeois" choreographers included those collectively referred to as the Big Four who utilized codified techniques and who contended that an artist could transcend time and place through the universality of formalist art (Graff 1997, 10). Revolutionary, or leftist, dancers were "those responding to Marxist doctrines," while "bourgeois" dancers, labeled as such by the leftist press, were ostensibly "independent of specific political ideology"; furthermore, radical dancers were not necessarily working for the Communist International, but they wanted societal change (Graff 1997, 13). While some of these dancers made agit-prop work that often displayed limited technical and professional training, many of them used a strong, defined technical base in dances with social messages, thus earning Prickett's further identification among the revolutionary dancers between "the agit-prop (agitation-propaganda) groups and those of [more technical] left-wing modern dancers" $(1994,15)$. It is significant to note, as Prickett emphasizes, that not all leftist dancers were Communists $(1994,14)$, and in fact, being labeled "red" in the press became an insult because it inferred a lack of technical training (see Ocko 1936b, 23). Sokolow was a left-wing modern dancer while also leading a revolutionary—but not agit-prop-group.

Sokolow's charismatic performance qualities and piercing choreographic statements catapulted her to the forefront of both modern and revolutionary dance during the nascent years of both forms. She garnered critical praise once she started choreographing with her first company, the Theatre Union Dance Group, in 1933. Sokolow formed this group under the auspices of the Theatre Union, which, also established in 1933, answered a desire among workers to have theatrical performances that reflected their concerns that were not, as a reviewer noted in New Voices, "too highbrow in their conception for [workers' audiences] to enjoy" (Morrison 1938, 6). Sokolow's artistic concerns aligned with this sentiment, and her group's first performances were for workers' unions (Lyle 1979, 141). She filled her group with dancers from Graham's company and school (Warren 1991, 44), with the purposes, as she stated in press materials, of "perform[ing] revolutionary dances at all labor organizations" and "producing revolutionary dances for performance" (New Dance: Special Recital Issue 1935; Workers Dance League 1934). Critical discourses indicate 1934 as the beginning of Sokolow's ascendancy as a prominent choreographer. In 1935, Sokolow changed the name of her group to Dance Unit. By 1937, Dance Unit was an independent and highly acclaimed dance group performing in Broadway theaters, in addition to workers' halls and the Jewish cultural institution and the prominent modern dance venue of the 92nd Street YM/ YWHA ("Y"). .9 Thus, Sokolow reached a multitiered progressive audience that included the alreadycommitted leftists and a broader population of modern dance attendees.

In addition to attracting U.S. critical support, Sokolow caught the attention of Mexican intellectuals and government officials, who shared social and artistic values of Communist ideology with the U.S. left in the 1930s, including producing artwork, like that of muralists Diego Rivera and David Alfaro Siqueiros, that melded established form with social content (see Rochfort 2006). The Mexican government's embrace of Sokolow evidences how her work spoke specifically to these values. Carlos Mérida, director of the Dance Department of Mexico's Instituto Nacional de Bellas Artes (National Institute of Fine Arts), invited Sokolow to Mexico City in 1939 under the auspices of the Ministry of Education in order to, according to Margarita Tortajada Quiroz, "[establish] an experimental Mexican school of modern dance" modeled on Graham's school and, specifically, Sokolow's work therein: dance focused on social issues that used a fully expressive body and that stressed the collective over the individual $(2001,357-8) .{ }^{10}$ Sokolow's subsequent work in Mexico on six-month tours through the 1940s, as revolutionary dance faded in the U.S. by the late 1930s and all but disappeared as an independent genre in the U.S. by the end of World War II, provided Sokolow with venues and audiences with which to continue her proletarian work through the war. Her wartime dances of Jewish cultural themes and her postwar 
choreographies of urban alienation and isolation, many of which she developed or premiered in Mexico, display veiled Communist ideology in their themes of anti-totalitarianism and humanitarian justice.

Sokolow officially aligned herself with Communist political principles when she registered as a Communist, instead of as a Socialist, Democrat, or Republican, during New York's 1936 general elections (Board of Elections 1936, 56). She embodied these ideals long before her official association with Party politics, however, and long after she cut her Communist ties in the 1950s. ${ }^{11}$ Many Communist ideals were present in the circles in which Sokolow traveled, and many of the themes in her work implicitly signified these ideas to "fellow travelers" (Communist sympathizers; see Denning 1996, 57-8). According to Jane Dudley, a leftist dancer and choreographer who also trained and performed with Hanya Holm and Martha Graham, the Communist platform provided leftist dancers with social and political theory in which they could base their choreography (Dudley 1981, 5). The Communist ideals and belief systems that grounded Sokolow's work through her career included equality for workers, justice for the masses, union activity, and racial equality.

Sokolow's principles resonated with political changes in the U.S. in the mid-1930s, which concert dance, in turn, reflected. The Popular Front, one of the most influential social movements in the U.S. during the 1930s, which Michael Denning defines as "a radical social-democratic movement forged around anti-fascism, anti-lynching, and the industrial unionism of the CIO [Congress of Industrial Organizations]," was intimately connected with themes and activism in both modern and revolutionary dance (1996, xviii). While the Popular Front was not affiliated with the American Communist Party, many people associated with this "Old Left," including revolutionary dancers, were Communists or "fellow travelers" (Denning 1996). With the rise of the Popular Front, making work for social change became popular. Graham and Humphrey made dances about social issues due to the change in the climate that accepted political protest, and the revolutionary dancers and the critics who supported them pressured the Big Four dancers to address social issues (Conner 1996, 238-40; Franko 1995, 27; Geduld 2008, 56). Denning's examination of the Popular Front's accompanying cultural apparatus, which he labels the Cultural Frontincluding the arts, entertainment, literature, and advertising-brought the arts to the political front lines as it was, as Denning posits, the "laboring of American culture" (1996, xvi-xvii and 50). Sokolow's embodiment of this "laboring" in her choreography spoke to the time period's larger social current.

Sokolow's prominence in leftist outlets beyond concert dance reinforced her onstage power. While Sokolow choreographed large-scale pageantry including her Dance of All Nations at the New York State Committee for the Communist Party's 1938 Lenin Memorial Meeting at Madison Square Garden, dance sequences for the Negro Cultural Committee's revue The Bourbons Got the Blues (1938), and the Federal Theatre's musical Sing for Your Supper (1939), her earlier choreography for the concert stage provided embodied protest that was conversely disseminated beyond revolutionary audiences, largely due to attention from mainstream critics such as John Martin. Sokolow performed at U.S. Communist rallies into the early 1940s, while she focused her concert dance themes during this time on anti-fascism. Her continued presence in these spaces is evidenced by her contribution of a group of dances that the Daily Worker highlighted as "a special feature of the evening" to a February 5, 1943, Lenin Memorial Meeting in Hartford, Connecticut ("Minor at Lenin Rally" 1943, 4). In the 1950s, under the specter of the Second Red Scare and under FBI surveillance, Sokolow denied her allegiance to Communist projects. In a 1955 affidavit and interview recorded in her FBI file, Sokolow cited that her participation in such events was in support of their ideological protests, including civil rights violations, and aid for Spanish War veterans or Russian War relief, and that she performed at these rallies to earn a living. ${ }^{12}$ Significantly, all of her work during this time reflected Communist and Popular Front goals, and she remained relatively consistent in her political alignment. ${ }^{13}$ Sokolow continued her Communist affiliations through the late 1940s, long after many American Communists cut their ties to the movement 
due to the 1938 formation of the Dies Committee, the 1939 Nazi-Soviet Pact, and the 1946 re-formation of the House Un-American Activities Committee (HUAC) at the forefront of the postwar Second Red Scare. ${ }^{14}$ Sokolow's proletarian dances, imbued with her Communist ideals, formed the basis of her choreographic career. The critical reception of her group and solo compositions such as Strange American Funeral and Case History No.- portrayed a larger dialogue of protest and enabled Sokolow the representative power to be both working-class and elite, Jewish and white, Communist and mainstream.

\section{Traversing Critical Divides}

Critics played a crucial role in mediating public dialogue about and in defining the young forms of modern and revolutionary dance in the 1930s. Two of the most influential critical voices in the 1930s discussion defining concert dance were those of John Martin, who wrote in The New York Times, and Edna Ocko, who wrote under her name and various pseudonyms in leftist publications including New Theatre and New Masses. Martin, who was largely responsible for Martha Graham's rise in artistic prominence and was notorious for his disparagement of leftist protest, valued strong technique, professional training, and formalist craft; he identified modern dance through the lenses of abstraction and universalism. Ocko, a champion of the revolutionary dance movement, valued concert dance professionalism and defined it as a marriage of technical ability, craft, and social message. Critics in the dance-focused publications Dance Magazine, The American Dancer, and Louis Horst's Dance Observer addressed issues defining modern and revolutionary dance along similar lines.

Lively debates between critics and dancers about the definitions, missions, and aesthetics of modern and revolutionary dance fill the pages of 1930s periodicals. ${ }^{15}$ Points of interest included how propaganda work could (and should) be strongly crafted by concert dance standards in addition to embodying social protest, and how revolutionary dancers could not simply "put on" proletarian airs for leftist work, but they had to live and understand the working-class experience. ${ }^{16}$ Michael (Mike) Gold, a founder of New Masses and one of a group of writers who defined proletarian literature, ideologically supported and was supported by the revolutionary dance movement (see Denning 1996, 200-5). In a 1935 interview, he expounded, "Real proletarian writers must, essentially, understand the class struggle" (Weisser 1935, 9). Ocko echoed this statement when she wrote that revolutionary dancers had to embody their proletarian themes: "Working-class ideology, no matter how thinly sketched, cannot be superficial integument slipped on to any skeleton of a dance technic $[s i c]$, nor can it be an innovation in movement imposed on to an idea that becomes revolutionary by annotation" $(1934,27)$. Thus, although technical prowess was essential to revolutionary choreography, choreographers had to present a marriage of proletarian content with technical form in order to be fully considered revolutionary; it also helped if the choreographer came from a working class background. Sokolow thus embodied this ideology.

Combined support from across the critical spectrum allowed Sokolow to be in multiple representational spheres at the same time. The leftist press recognized Sokolow as a professional artist whose work was simultaneously choreographically astute and ideologically potent. Critic Margery Dana triumphantly reported in the Daily Worker in 1937, "By this time, Miss Sokolow has revealed that she is one of the foremost figures in the modern dance. Where other dancers and groups are still faltering and groping to find new paths, Anna Sokolow's recital reveals a revolutionary dancer of the first rank striding on a solid road" (7). That the most detailed movement description of revolutionary dance, especially Sokolow's choreography, comes from the leftist press exemplifies the importance of concert dance-and Sokolow's work-to the revolutionary cause.

John Martin's support separated Sokolow from her working-class Jewish leftist contemporaries. In his 1936 book America Dancing, Martin similarly praised Sokolow, yet denied her the strength that 
Dana extolled when he noted that she "appear[ed] to be destined for the front rank of the next generation of dancers-completely individual, forthright and unaffected, not as yet especially profound, but with a rare lightness of touch that is ample compensation for the time being" (281). Sokolow was not generally known for her "lightness of touch," and Martin's denial here of her direct social statements strips her work of this aspect. Martin consistently bolstered Sokolow in his frequent reviews of her work, which is significant especially in light of his 1935 "full-scale attack on the Workers Dance League" (Graff 1997, 10), but he only discussed its formalist elements and refused to acknowledge Sokolow's proletarian content. By doing so, as Mark Franko notes, Martin sanitized revolutionary dance, especially for Sokolow: "Martin gives Sokolow a leading place in the modern dance movement at the price of a theory that depoliticizes her dances" $(2002,117)$. Sokolow's political and artistic aims were a secret neither in the Jewish and secular socialist circles that trumpeted her themes, nor in the modern dance circles that praised her composition and technical ability. Her high level of professionalism paired with critical support that highlighted the modernist aspects of her work placed her squarely within the discourse as an artist with broad appeal instead of as a working-class, Jewish, Communist dancer.

As Sokolow's work evolved, so too did definitions of revolutionary dance. Her work initially appeared too close to the abstracted concert dance associated with the Big Four for Dance Observer critic Henry Gilfond to even group her with her WDL colleagues. In 1934 he wrote that Sokolow's "work can hardly be termed 'red"' because her choreography was more metaphorical and less literal than the other WDL compositions on the concert, and thus presumably more "art" and less propaganda (89). This critical view changed over the next few years, as in 1934 the Communist Party espoused a policy of socialist realism that, as Graff notes, "urged collaboration with bourgeois artists" (1997, 10), thus sanctioning revolutionary dancers to incorporate modernist compositional tools into their choreographic methodologies. Critic Elizabeth McCausland expounded in western Massachusetts' Springfield Morning Union in 1937 that the power of Sokolow's work came "by bending the dance technic [sic] she learned under Graham ... to the service of social art.... [The audience's] ardent bravos proved that in the wedding of form and social theme, Anna Sokolow was offering them reality they had not found elsewhere in the dance." Similarly, New Masses critic Owen Burke labeled Sokolow's Opening Dance (1937) a manifesto that demonstrated her proletarian allegiance through its focus on "the people" as "the source and substance of her dancing" (Burke 1937b, 28). In a 1942 interview, Sokolow continued this reasoning when she declared to critic Margaret Lloyd that dance "is influenced by the life of the common man ... [it] draws its life from the people" (quoted in Lloyd 1942). As revolutionary dance embraced modernist form, Sokolow poised herself to disseminate her message of social change in a language that spoke to audiences with varying degrees of proletarian sympathy. Strange American Funeral and Case History No.exemplify this communication.

\section{Dancing for Justice}

Strange American Funeral (1935) was one of the most popular modern and revolutionary dances of the mid-1930s (see Photo 1). Sokolow considered the piece, which premiered in a New Dance League Festival on June 9, 1935, propaganda for the worker's cause (Warren 1991, 66). The dance furiously blamed the capitalist establishment for the wrongful death of hundreds of miners and steel workers. Imagery in the movement and textual accompaniment transformed flesh into steel and human into machine (Franko 2002, 116). In it, Sokolow spoke directly to the plight of the worker and incorporated proletarian discursive trends within stylized choreographic patterns. The dance's haunting tone created a clear separation between the oppressed worker and the hegemonic power structure against which Sokolow railed.

Sokolow culled the libretto and musical accompaniment for this dance from her leftist art and literature circles. She based the dance on Mike Gold's poem "Strange Funeral in Braddock," and set it 


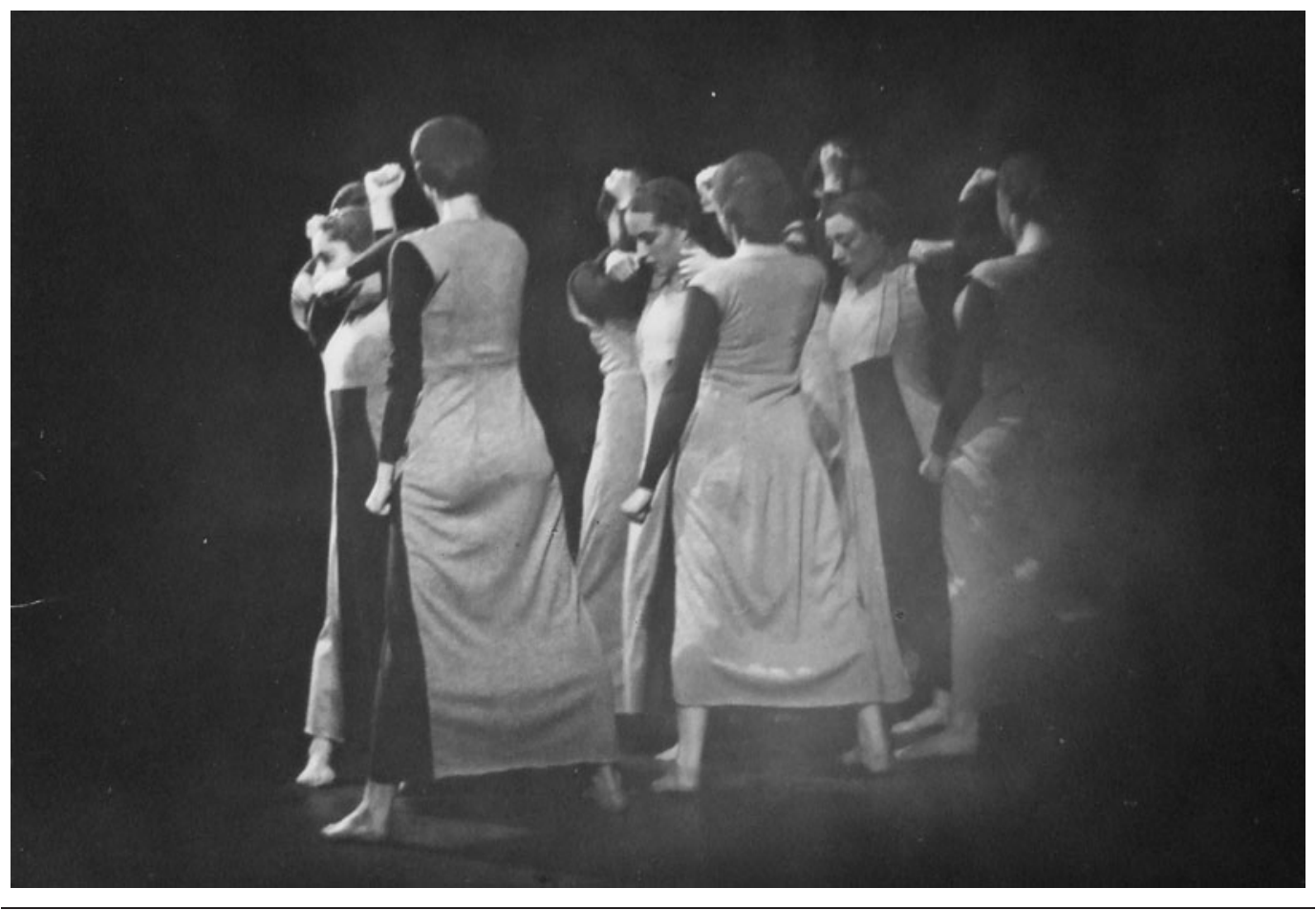

Photo 1. Dance Unit in Strange American Funeral (1935). Photographer unknown. Larry Warren Collection. Music Division, Library of Congress, Washington, DC.

to leftist composer Elie Seigmeister's musical rendition of the poem. Gold's verse narrates the story of Jan Clepak, an Eastern European immigrant steel worker in Pennsylvania who daydreams at his puddling trough and plunges to his death in the molten metal when a broken guardrail fails (Gold quoted in New Dance League June Dance Festival 1935). An accompanying program note asserts that Clepak was "a worker who was caught in a flood of molten ore-whose flesh and blood turned to steel ..." (Anna Sokolow and Dance Unit 1936). The poem's haunting refrain patters, "Listen to the mournful drums of a strange funeral. / Listen to the story of a strange American funeral!" (Gold quoted in New Dance League June Dance Festival 1935). Gold juxtaposes the imagery of Clepak as a "soft man," who mused about his family's future and Braddock's rolling hills, with the hard metal of his occupation and the hardened version of his body at his death. Clepak's widow proclaims, "I'll make myself hard as steel, harder! / I'll come some day and make bullets out of Jan's body / and shoot them into a tyrant's heart ..." (Gold quoted in New Dance League June Dance Festival 1935). This scenario occurred within the Pennsylvania steel industry where Frederick Winslow Taylor, according to Franko, "experimented with combinations of time expenditure and the exertion of physical effort among workers" (2002, 22). That Clepak became metal after falling out of step with Taylorized efficiency heightens the statement to expose the inhumane, mechanized conditions under which workers toiled. The musical score supports the mutation from flesh to steel within workers' cultural performance. According to Carol T. Oja, the rhythm and pace of Seigmeister's score "recall[ed] that of proletarian chants at mass meetings," while the music featured "melodic angularity, disjunct rhythms, and spiky dissonance" (1988, 163, 173). Sokolow brought the rhythm and fervor of proletarian culture's mass meetings to the concert stage. Though critics do not report this, one could imagine such chanting or kinesthetic audience participation in the theater as well.

The solemnity of fated wrongful death resonated throughout the dance. The piece opened with a funeral cortege: a group of women clad in long utilitarian dresses, their heads tightly covered by 
black hairnets, held a still dancer aloft as they slowly traversed the stage while singer Mordecai Bauman ominously rang out the refrain: "Listen to the story of a strange American funeral!" (Oja 1988, 161-2; Warren 1991, 65). Critic Stanley Burnshaw reported in New Masses that Bauman's eerie amplified voice in his recitation of Gold's poem provided "a strange quality supremely attuned to the needs of the dance" (1936). The rest of the dance was a narrative flashback that portrayed Clepak's gruesome death and workers' anger in response to it. In demonstrating their resistance against workplace supervisors and the businessmen who ran these mills, who appeared in the form of what John Martin described as "two pompous masked figures representing directors [who] enter[ed] the scene" halfway through the piece (Martin 1935b, 4X), the dancers struggled against one another's restraining locked arms, portraying the necessity to break free. Ensuing group movement patterns weaved through each other with escalating potency until, Burnshaw noted, the dance "achieve[d] a summit of militancy and accusing power" that produced a force which increased in intensity as it was fed by outrage associated with each new worker's death $(1935,43)$.

The layering of geometric formations remained Sokolow's vehicle of creating choreographic intensity through the work. This tool matched the build in the musical intensity, which in turn reflected the poem's typeface wherein the letters of the refrain became larger down the page (Hicks et al. quoted in Oja 1988, 179). Burnshaw pointed to the "constant freshness and 'inevitableness' with which the dancers flow from one design into another" (1936). These "inevitable" designs stirred the sentiment of social unrest in this work, wherein Sokolow aimed to empower the masses to rise up against dominant power structures. Since the poem "Strange Funeral in Braddock" was intended for chanting at mass meetings (Oja 1988, 178), Sokolow's translation of a text already charged with proletarian activist sentiment to the concert stage through her "inevitable" choreographic patterns cemented it within a concert performance arena through women's bodies.

The trope of funerals for workers who died on duty, specifically those of miners, appeared in New Masses stories and cartoons during the mid-1930s. Such a funeral was tragic yet dignified. In Emery Balint's 1934 "Miner's Funeral: A Short Story," the funeral was an event of pride, of dignity, and of belonging; there was also a sense of loyalty when the person was a union member and not a scab. Additionally, in a political cartoon titled "Miner's Homecoming," two men lift a lifeless body onto a bed as the small house fills with family and friends looking on (Krackman 1937, 7). Clepak's steel worker story shares with the miner trope a culture of active unions in physically demanding and dangerous jobs. By using Gold's poem as a libretto with Seigmeister's score, Sokolow aligned herself with Communist sentiments with a manner and message familiar to her audience.

The contemporary reviews lack substantial movement description of Strange American Funeral, even though critics dedicated significant amounts of space to its coverage. Most writers expound upon the narrative's gruesome outcome, and comment on Sokolow's ability to affect the masses with her choreography. While after its premiere John Martin thought "the dance as a whole was inchoate and pointless" (1935b, 4X), most likely due to its theme and what he saw as its incomplete success of incorporating movement and text, he noted, "Many individual passages of her composition were superb not only in their integrity of feeling but in their boldness of imagination" (1935a). Franko asserts that Martin's tirade about Sokolow's choice to set the dance to a poem masks Martin's opposition to Sokolow's thematic material (2002, 114-5). Later that year, when Sokolow presented Strange American Funeral on a shared concert with Graham, Humphrey, Weidman, and Tamiris, Martin remarked that Sokolow's Dance Unit "has proved before now its right to be seen with the best" (1935c, 23). Martin, with the least amount of attention to the dance but the most amount of space to cover it, was alone in his criticisms.

Other critics and dancers received Strange American Funeral as a beacon and pronounced its impact. Henry Gilfond noted in Dance Observer that Strange American Funeral "[was] definitely a major work in creation, grows sharply and distinctly as one of the most significant compositions in contemporary dance. It is by far the best of Anna Sokolow's dance works" (1936). Similarly, 
Marjorie Church wrote in Dance Observer that the dance "[was] particularly moving, largely because of its suggestion of generality and its overtone of protest" (1937b, 41). Many critics writing in leftist publications praised the work. Edna Ocko highlighted Strange American Funeral as one of New Theatre's best dances of 1935 that "achieved complete, or almost complete, realization of their purpose" (1936a, 24). Louise Mitchell wrote in the Daily Worker two years after the dance's premiere, "Dances with the choreographic strength of 'Strange American Funeral' grow in intensity with each repetition" (1937). Jane Dudley considered Strange American Funeral Sokolow's best revolutionary dance (Dudley 1981, 6). This reception reinforces the dance's resonance for the time period, and even, to connect back to Barnes' characterization of Sokolow as a "prophet of doom," shows Sokolow as a soothsayer with her finger on the pulse of contemporary sentiment.

While in Strange American Funeral Sokolow projected one incident as a larger example of societal problems through the bodies of a corps of women, in Case History No. - she generalized the plight of a large group of impoverished youth ignored by the elite through her solo body, which represented male street urchins. Sokolow premiered Case History No.- on February 28, 1937, at the 92nd Street Y. In addition to performing it often in New York and Mexico City through 1939, in 1939 Sokolow presented the solo under the title "Crime pays-Until" as the second part of a longer group work called The Street (Warren 1991, 306). An accompanying program note at the 1937 premiere reads, "A study of a majority of case histories shows that petty criminals usually emerge from a background which begins with unemployment and follows its course from street corner to pool room, from mischief to crime" (Dance Recital by Anna Sokolow 1937). ${ }^{17}$ Here, to a score by Wallingford Riegger, Sokolow embodied her proletarian ideals, yet the perceived universalism of the dance allowed her to subvert gender expectations through an androgyny that emerged onstage. ${ }^{18}$

Even though she wore a fitted long-sleeved black shirt with two white stripes over the left bicep and a tweed-like skirt, and the program note does not denote a gender of the "petty criminals," the youth she portrayed in the characterization was perceived as gendered male; in reviews, critics refer to Sokolow as a young man. According to Daily Worker critic Louise Mitchell, "Anna Sokolow depicts the lifetime of thousands of youths who roam this country as vagrants and petty criminals.... She dances of their boyish bravado, their willfulness, frustration, desperation, the hunted suspect, the third degree, the cringing boy killers, the last mile" (1937). It is curious, though, that the critics portray Sokolow as a male thug and not as a prostitute-a female archetype who would have also wandered those streets. The diminution of Sokolow's female gender reflects the Communist trope of gender-neutral ranks of comrades, and it also reflects the 1930s convention of white and Jewish women choreographers to transcend the specificity of their race and gender in performance to make a universal statement (see Jowitt 1988, 191; Manning 2004, 12). ${ }^{19}$ In this dance, Sokolow occupied rough, urban male space rarely attributed to women's habitation due to its danger, yet since she lived among the impoverished tenements as a child, she personally knew this space well (see Graff 1997, 71). As this dance thus answered Gold and Ocko's call for choreographers to live or understand their proletarian dances' material from the inside out, it also reinforced Sokolow's ability to transcend gendered specificity while embracing the working-class struggle.

Sokolow embodied these youths' gritty existence while performing with a polished focus and intensity that showcased her technical range and her fiery, scrappy performance charisma. The work plumbed emotional depth; one of her former dancers remembered Sokolow's heart-wrenching performance of the abandoned child's palpable experience of alienation (Mackenzie 1987, 13). Sokolow exhibited concentrated power, oppositional tension, and a broad dynamic range in this dance. She portrayed, as critic Margery Dana noted in the Daily Worker, "the sordid playgroundperhaps a street in 'Hell's Kitchen'-of the children of the poor” $(1939,7)$. The dance contained flying shapes, arrested motion, and pained solitude. One movement sequence included what Marjorie Church described in Dance Observer as a "slow, walking [movement motif], forward and back, which suggested miles of city streets traversed, corners paused at and finally turned, 

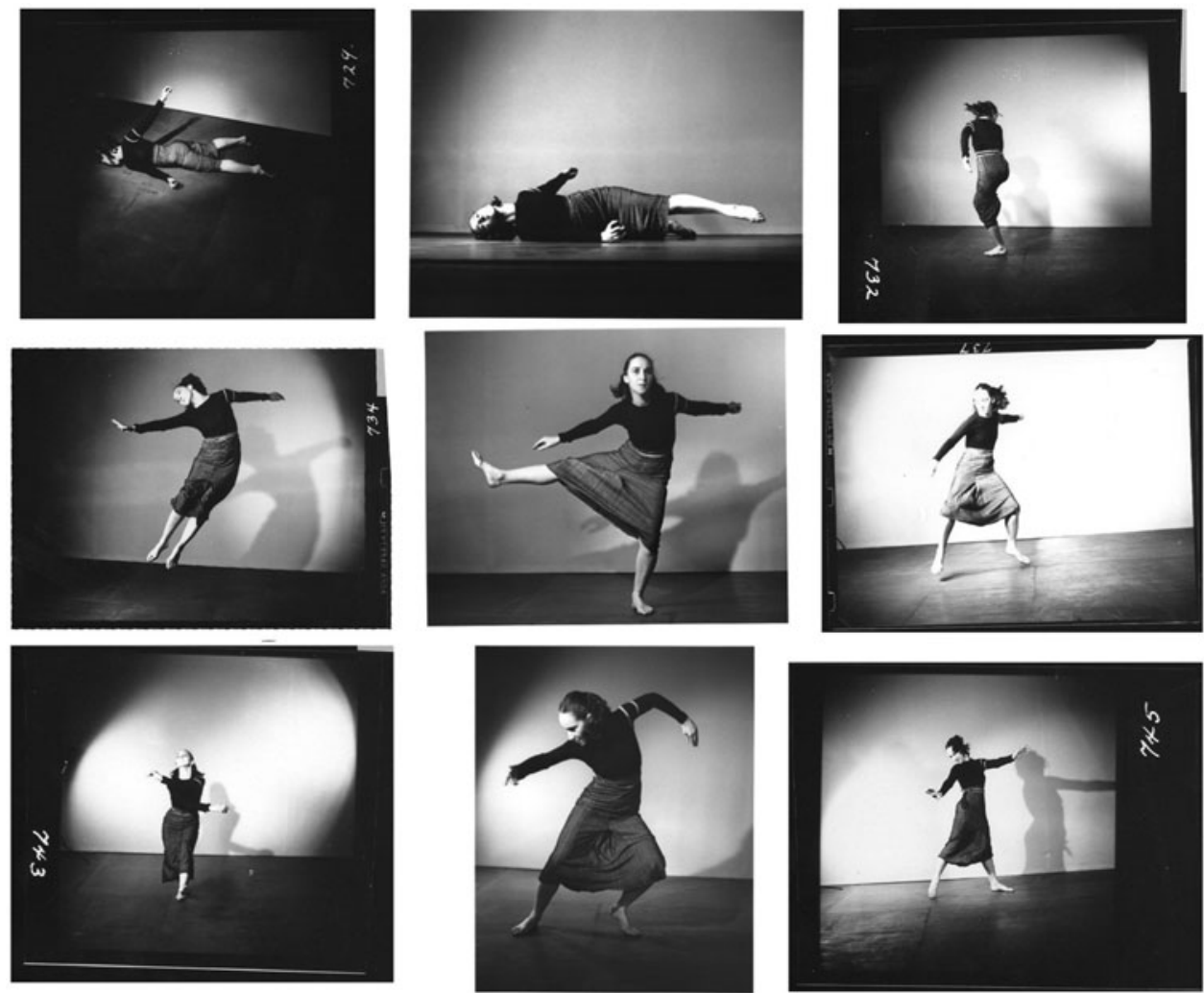

Photo 2. Anna Sokolow in Case History No.- (1937). This grid includes proofs and prints. I determined the order of the images by the proof numbers, but this is not necessarily the order of the dance. It appears that Sokolow may have run through the dance two or three times during the photo shoot. Photographs 1941, () Barbara Morgan, Barbara Morgan Archives.

cups of coffee now and then in grubby little dives" (1937b, 41). Sokolow addressed her audience members over her left shoulder, as her cold stare accused them of causing her misery and at the same time appealed to them for help. ${ }^{20}$ In a series of photographs by Barbara Morgan (see Photo 2), Sokolow bends her body into a mid-air crescent as she sadly gazes into space; she whips her left arm behind her body as she hovers just above the ground; and prone, she painstakingly peels her limbs off the floor, wringing her body as she exposes her vulnerable ventral surface, which, along with her face, were previously smashed into the floor. Sokolow's dirty bare feet in these images verify her embodiment of the material, as if she wandered shoeless through New York City.

The rhythms in the music and the movement evoked an unstable cityscape. Critic Owen Burke wrote in New Masses that the dance was "[i]ntense in structure, literally tearing away at space in a nervous staccato rhythm, dominated by a desire for security" (1938, 30). Sokolow employed syncopated rhythms and what Burke called "a neurotic bravado" to construct an urban pace and environment $(1937 \mathrm{a}, 28)$. In one photograph, Sokolow seems to take off across the space: she quickly shifts her weight onto her bent left leg, leaving her right leg behind, as her left elbow slices behind her and she focuses intently into the palm of her right hand. The opposing tensions, displaced joints, and jagged lines through her body, from her left elbow to her right knee, through her torso slightly bent over the right side of her waist, and from her cocked right wrist to her flexed left hip and knee, resemble the polycentrism and ephebism that Brenda Dixon Gottschild (1998) 
identifies as part of the Africanist aesthetic in American dance. ${ }^{21}$ As Case History No.- addressed problems of poverty in the city's poor and immigrant neighborhoods, it also portrayed a metropolitan America where Eastern-European- and Southern-European-immigrant and Africanist influences met in expressions of the class struggle (see Manning 2004).

Case History No. - exposed the dark underbelly of a city failing to protect its poorest and youngest members. These young people, Sokolow implies, have no choice but to lurk in allies and engage in illegal behavior. Critic Marjorie Church's Dance Observer review reflects in her comments that the "dance suggested very well the energy and loneliness of youth trying to adjust itself to false and unfriendly conditions; the sense of futility and the growing despair in the youth become the force which drives him toward defiant and anti-social acts" (1937b, 41). Similarly, Louise Mitchell, also writing in Dance Observer, asserted that the piece was "a burning indictment against society and the first great revolutionary dance characterization" (1937). In the dance she saw "the countless Ted Di Dionnes who never got a chance, whose only crime was being born into a society that breeds them and then destroys them like gutter rats" (Mitchell 1937). As she used this dance to point to societal injustices, Sokolow nevertheless presented an American portrait in these "countless" criminals. In the aftermath of solos such as Graham's Frontier (1935) that portrayed a hearty woman of heroic femininity surveying the vast horizon as a synecdoche of mythic Americana ideals, Sokolow's solo here portrayed not only an urban, immigrant outsider to presentations of fabled (white) pioneers pushing west, but a gendered difference as well. Sokolow was not a productive woman, but a destructive boy. This presentation fed Sokolow's later work in terms of American urbanity and gender performance. Case History No.-, with its jazz score, sentiment of workingclass alienation in urban environs, and androgynously gendered spaces, served, according to Larry Warren, as an early solo study for Rooms (1954) — Sokolow's seminal work of urban alienation and isolation $(1991,70)$.

The attention Strange American Funeral and Case History No.- attracted shows the circulation of Sokolow's work among hybrid audiences. Strange American Funeral premiered at a NDL festival at the Park Theatre in Columbus Circle, was subsequently performed later that year at Carnegie Hall on a shared concert with Graham, Humphrey, Weidman, and Tamiris, and at the 92nd Street Y the following year on a Dance Unit program (Anna Sokolow and Dance Unit 1936; Martin 1935c; New Dance League June Dance Festival 1935). Case History No.—, which became one of Sokolow's signature solos, premiered on a Dance Unit program at the 92nd Street Y (Dance Recital by Anna Sokolow and Dance Unit 1937). It appeared on the program for Sokolow's Broadway debut at the Guild Theatre later that year (Dance Concert Debut 1937), as well as on countless programs in the following years in various New York venues and for audiences of workers, artists, and intellectuals in Mexico City's opera house, the Palacio de Bellas Artes (Anna Sokolow y su Cuerpo de Ballet 1939; La Paloma Azul 1940). ${ }^{22}$ Critics without overt leftist leanings identified with these dances even though the work did not speak to their social positions. Sokolow's choreography allowed middle-class audiences, who likely would not otherwise examine proletarian issues, to do so within a familiar aesthetic context of modernist ideals. The largely Jewish and middle-class audiences at the 92nd Street Y, which represented a mix of political views, also valued a combination of social and modernist content. For the proletarian audience, however, these pieces spoke to fears and issues in contemporary leftist discourse, including workers' rights and justice for the poor and underserved, while embodying the subjects in a way that was central to the needs and goals of revolutionary dance. Sokolow's pithy statements, scathing societal indictments, and fully expressive movement enabled her widespread navigation of these concert stages.

\section{Conclusion}

Even, and especially, as the women of Sokolow's Dance Unit swarmed around the stage in an empowered mass of mechanized bodies to agitate for workers' rights in Strange American 
Funeral, the abstraction of the movement allowed the dancers to portray men and women workers. This choreography provided a social statement that spoke both to Communists and to "fellow travelers," as well as to progressive audience members who aligned themselves primarily with modern dance but who appreciated social protest. Compositional elements in Case History No. - that Sokolow learned from Graham and Horst similarly enabled her to make specific proletarian indictments in broader, even universal, terms. Sokolow aligned herself with American Communism in the 1930s, in ideology, in artmaking, and in social political affiliation, and reviews suggest that she built her dances more effectively than many of her contemporaries.

The historical downplaying of Sokolow's Communist ideals reflects a larger trend in relation to leftist dancers and 1930s choreography. In a discussion of Communism and the New Dance Group, specifically of a cyclical American-Soviet cultural dialogue via the Communist Party and how it manifested in leftist dance, Victoria Geduld asserts: "In order to claim material agency for participants, historians have whitewashed concrete CPUSA political roots in the dance art. This dislocation undermines the potency of the Communist Party and does not address the nuances of a complex Soviet-US dialogue that had an impact on American cultural history" $(2008,43)$. Sokolow's actions, and the reviews of her work especially by John Martin, fall into this nuanced category. Her participation in such activities is significant in light of increasing U.S. government censorship of Communist activity during that time. Notably, the New York State Committee for the Communist Party and the Federal Theatre recognized Sokolow both as an artist and a revolutionary activist prominent enough to headline the dance aspects of their productions in the late 1930s (Dance of All Nations and Sing for Your Supper, respectively). Sokolow's social statements and technical precision gave her proletarian credibility and attracted concert audiences. Her Communist ideology in these proletarian dances solidified her reputation, attracted international attention, and sustained her career, yet it was also because of her Communist ideology that Sokolow had to reframe her reputation during the Cold War.

\section{Notes}

I thank the conveners and participants of the working group "Activist Choreographies: Pas de Deux, Mashups, and Other (In)Elegant Partnerships" at the 2010 conference of the American Society for Theatre Research and the Congress on Research in Dance for feedback on an early version of this article and for fostering the idea for me of "activist partnerships" in Sokolow's work. I extend deep thanks to Harmony Bench, Kate Bredeson, Clare Croft, Mark Franko, and my anonymous reviewers for their valuable feedback on this essay. Research was generously supported by the Melton Center for Jewish Studies at The Ohio State University, the P.E.O. International Sisterhood, and Reed College.

1. See Phelan's (1993) discussion of the representative power of being marked and unmarked.

2. Sokolow's Dance Unit included Aza Cefkin, Ronya Chernin, Rose Cohen, Celia Dembroe, Ruth Freedman, Eleanor Lapidus, Rose Levy, Marie Marchowsky, Ruth Nissenson, and Florence Schneider (New Dance League June Dance Festival Program 1935).

3. Foster (2003) demonstrates that physicality and participants' presence are vital to successful political demonstrations, and for participants' resulting sense of agency. Martin (1998 3, 39-46) identifies how this embodiment politically enlivens the space between the performers and the audience. My examination of the historical reception of Sokolow's work is also informed by Mark Franko's (2007) argument that politics in dance is related to its history, wherein dance and politics are intertwined and are also a matter of representation and interpretation.

4. See Warren $(1991,37)$ and Henderson (2003, 14-5) for comments, largely made by Sokolow's artistic and romantic partner Alex North, about Sokolow's "emotional" reactions to current events.

5. See Rossen (2011, 337-9). Jewishness is intimately tied to race and ethnicity in the early and mid-twentieth century, and Jews were not considered racially white until after World War II. See 
among others Erdman (1997), Jacobson (1998), Brodkin (2000), and Dash Moore and Troen (2001). The revolutionary dance movement consisted largely of Jewish women of Eastern European descent. Many of these dancers took Martha Graham's, Doris Humphrey's, and Charles Weidman's dance classes at the Lower East Side's Henry Street Settlement, and consequently danced in their companies. See also Tomko (1999), Foulkes (2000), Jackson (2000), and Manning (2004) for discussions about Jewish women in dance in the 1930s.

6. The photographs I reference here-Anti-War Trilogy and an unknown dance, and FaçadeEsposizione Italiana - are held, respectively, in the repositories of the Sokolow Dance Foundation and Barbara Morgan Archives. For published photographs of Sokolow performing as a younger dancer, see the plates in Warren (1991). Additionally, Graham movement ideals manifest in Sokolow's students, as she taught Graham technique in her own classes through her career. For photographs of Sokolow leading such a class, see Sorell $(1964,53)$.

7. Between 1934 and 1937, New Masses ran series of articles about Mexican muralist art and Mexican working-class politics. These include Siqueiros (1934), Wedger (1935), Alexander (1936), Toledano (1936, 1937), and Freeman (1937).

8. Graff notes that the content of the dances, and not necessarily the movement vocabulary, made them revolutionary $(1997,75)$.

9. See Jackson (2000) for the role of modern dance at the 92nd Street Y, and the role of the 92nd Street $\mathrm{Y}$ in the development and patronage of modern dance in the 20th century.

10. "En 1937, el pintor Carlos Mérida había presentado la única ponencia sobre danza dentro del Congreso de la LEAR, en la cual propuso se estableciera en México una escuela experimental de danza moderna ..."

11. Anna Sokolow, State of New York Affadavit, May 9, 1955, and transcript of FBI interview with Sokolow, November 1, 1955, U.S. Department of State, FOIPA No. 1138496-000. Additionally, in 1952, after nearly twenty years of voting with the Communist and American Labor parties, Sokolow registered as a Democrat (Board of Elections 1952, 17). Sokolow registered to vote for the last time in 1988, at which time she requested that she not be associated with any party (Board of Elections, Manhattan Borough Office 2010).

12. Anna Sokolow, State of New York Affadavit, May 9, 1955, and transcript of FBI interview with Sokolow, November 1, 1955, U.S. Department of State, FOIPA No. 1138496-000.

13. Sokolow's voting records exemplify this consistency of political alignment. While one could no longer vote as a Communist in 1944 and 1948, in these election years Sokolow registered with the American Labor Party (with choices in 1944 including American Labor, Democrat, or Republican, and in 1948 American Labor, Democrat, Liberal, or Republican; Board of Elections 1944, 143; Board of Elections 1948, 128). It is unclear if Sokolow registered to vote in 1940. Since she was in Mexico for the majority of that year, it is possible she did not register. It is also possible that, since I do not have a correct street address for her in 1940 (I have two from 1937, but clearly these were no longer accurate in 1940), I cannot locate her voting record for that year.

14. On November 8, 1948, Sokolow requested transfer from her International Workers Order (IWO) lodge in Manhattan to one in Brooklyn, effective January 1, 1949, signifying that she continued her membership with this organization, which was largely made up of Jewish Socialists (Memorandum, September 21, 1951, regarding November 8, 1948 Application for Transfer from Lodge No. 478 to Lodge No. 467, U.S. Department of State, FOIPA No. 1138496-000). In 1949, Sokolow attended the American Continental Congress for World Peace, which HUAC dubbed the "Communist Peace Offensive." See U.S. Congress $(1951,23)$. The Nazi-Soviet Pact aligned Hitler and Stalin in a non-aggression pact for the war, and ideologically aligned fascism and Communism, causing many Communists to discontinue their allegiance. Both the Dies Committee and HUAC worked toward the goal of outing and blacklisting Communists amidst climates of fear.

15. A selection of these articles is reproduced in the appendix to Dancing Modernism/ Performing Politics (Franko 1995, 109-144).

16. See, for example, Rudhyar $(1936,109,113)$. Rudhyar argues, furthermore, that in order for art to be vital, it must be embodied; otherwise, it is not art, but propaganda. One Boston-area critic took this further in scolding leftist choreographer Bill Matons, who was also a dancer with the 
Humphrey-Weidman company, for appearing energetically too well-fed in a solo about hunger. See Chase (1936).

17. The wording of this note changed slightly over the course of the dance's life, but the main ideas remained consistent.

18. Thank you to my anonymous reviewer for this clarification.

19. Deborah Jowitt notes how with modernist abstraction, "The strong women stood for Everyman" $(1988,191)$.

20. See photograph in Kriegsman $(1981,264)$.

21. Dixon Gottschild defines polycentrism: "From the Africanist standpoint, movement may emanate from any part of the body, and two or more centers may operate simultaneously," and ephebism: "Emanating from the ancient Greek word for youth (ephebe), this principle encompasses attributes such as power, vitality, flexibility, drive, and attack. Attack implies speed, sharpness, and force" $(1998,14-6)$.

22. In my larger project, I more fully address Sokolow's work and reception in Mexico City.

\section{Works Cited}

Alexander, Stephen. 1936. “Art: Orozco's Lithographs.” New Masses, November 19, 29. The Ohio State University Billy Ireland Cartoon Library \& Museum (hereafter OSU BICL\&M).

Anna Sokolow and Dance Unit. 1936. Program, April 5. 92nd Street Y Educational Department Records (hereafter 92Y).

Anna Sokolow y su Cuerpo de Ballet. 1939. Program, April 15. Acervo Histórico de Palacio de Bellas Artes, Mexico City.

Balint, Emery. 1934. "Miner's Funeral: A Short Story.” New Masses, January 16, 16-19. OSU BICL\&M.

Barnes, Clive. 1968. "Dance: Anna Sokolow, Poet of Chaos." New York Times, November 14, 54. Proquest Historical Newspapers (accessed February 26, 2012).

Battey, Jean. 1967. "The Dance - Choreographer Works Slippers Off Dancers.” The Washington Post, January 18, n.p. Alan M. and Sali Ann Kriegsman Collection, Music Division, Library of Congress.

Board of Elections in the City of New York. 1936. List of Enrolled Voters. Tenth Assembly District, Borough of Manhattan. The New York Public Library Science, Industry, and Business Library (hereafter SIBL, NYPL).

Board of Elections in the City of New York. 1944. List of Enrolled Voters for the Year 1944-1945. Fifth Assembly District, Borough of Manhattan. SIBL, NYPL.

Board of Elections in the City of New York. 1948. List of Enrolled Voters for the Year 1948-1949. Fifth Assembly District, Borough of Manhattan. SIBL, NYPL.

Board of Elections in the City of New York. 1952. List of Enrolled Voters for the Year 1952-1953. Ninth Assembly District, Borough of Manhattan. SIBL, NYPL.

Board of Elections, Manhattan Borough Office. 2010. Telephone conversation with the author. June 23.

Brodkin, Karen. 2000. How Jews Became White Folks and What that Says about Race in America. New Brunswick and London: Rutgers University Press.

Burke, Owen. 1937a. "The Dance." New Masses, March 16, 28-30. OSU BICL\&M.

—. 1937b. "Anna Sokolow and Other Dancers." New Masses, December 7, 28-30. OSU BICL\&M.

- 1938. "Dances for Spain and China." New Masses, February 15, 29-30. OSU BICL\&M.

Burnshaw, Stanley. 1935. "The Dance: Finale to a Brilliant Season." New Masses, July 2, 43. OSU BICL\&M.

— 1936. "The Dance," New Masses, January 7, n.p. Anna Sokolow Clippings, The Jerome Robbins Dance Division of The New York Public Library for the Performing Arts (hereafter JRDD, NYPL). 
Chase, William T., Jr. “The Theater: Repertory, New Dance League.” The Boston Herald, April 11, 14. Dance Clippings, New Dance League Folder, Harvard Theatre Collection (hereafter HTC). Church, Marjorie. 1937a. "The Dance in the Social Scene." Dance Observer, March 30, 32.

—. 1937b. "Anna Sokolow and Dance Unit, Major Subscription Series, YMHA, Sunday, February 28, 1937.” Dance Observer, April, 41. Anna Sokolow Clippings, JRDD, NYPL.

Conner, Lynne. 1996. "What the Modern Dance Should Be': Socialist Agendas in the Modern Dance, 1931-38." In Crucibles of Crisis: Performing Social Change, edited by Janelle Reinelt, 231-248. Ann Arbor: University of Michigan Press.

Dana, Margery. 1937. "Anna Sokolow and Dance Unit in Prominent Debut." Daily Worker, November 20, 7.

—. 1939. "Anna Sokolow and Unit Seen In New Solo and Group Dances.” Daily Worker, March $1,7$.

Dance Concert Debut by Anna Sokolow and Dance Unit. 1937. Program, November 14. Martha Hill Papers, The Juilliard School Archives.

Dance Recital by Anna Sokolow and Dance Unit of the New Dance League. 1937. Program, February 28. $92 \mathrm{Y}$.

Dash Moore, Deborah and S. Ilan Troen, eds. 2001. Divergent Jewish Cultures: Israel and America. New Haven and London: Yale University Press.

Denning, Michael. 1996. The Cultural Front: The Laboring of American Culture in the Twentieth Century. London and New York: Verso.

Dixon Gottschild, Brenda. 1998. Digging the Africanist Presence in American Performance: Dance and Other Contexts. Westport, CT and London: Praeger.

Dudley, Jane. 1981. Interview with Richard Wormser. Transcript. The Tamiment Library and Robert F. Wagner Labor Archives, New York University.

Erdman, Harley. 1997. Staging the Jew: The Performance of an American Ethnicity, 1860-1920. New Brunswick: Rutgers University Press.

Foster, Susan Leigh. 1986. Reading Dancing: Bodies and Subjects in Contemporary American Dance. Berkeley: University of California Press.

- 2003. "Choreographies of Protest." Theatre Journal 55 (3): 395-412.

Foulkes, Julia L. 2000. “Angels 'Rewolt!': Jewish Women in Modern Dance in the 1930s.” American Jewish History 88 (2): 233-252. Index to Jewish Periodicals, EBSCOhost (accessed February 20, 2008).

Franko, Mark. 1995. Dancing Modernism/Performing Politics. Bloomington and Indianapolis: Indiana University Press.

- 2002. The Work of Dance: Labor, Movement, and Identity in the 1930s. Middletown, CT: Wesleyan University Press.

—. 2007. "Dance and the Political: States of Exception." In Dance Discourses: Keywords in Dance Research, edited by Susanne Franco and Marina Nordera, 11-28. London and New York: Routledge.

Freeman, Joseph. 1937. "Trotsky in Coyoacan.” New Masses, March 23, 14-16. OSU BICL\&M.

Geduld, Victoria Phillips. 2008. "Performing Communism in the American Dance: Culture, Politics and the New Dance Group." American Communist History 7 (1): 39-65.

Gilfond, Henry. 1934. "Workers' Dance League, Civic Repertory Theater, November 25th, 1934." The Dance Observer, December, 89-90.

- 1936. "Anna Sokolow and Dance Unit, Theresa Kaufmann Theatre, Sun. Eve., April 5, 1936.” Dance Observer, May, n.p. Anna Sokolow Clippings, JRDD, NYPL.

Graff, Ellen. 1997. Stepping Left: Dance and Politics in New York City, 1928-1942. Durham and London: Duke University Press.

Henderson, Sanya Shoilevska. 2003. Alex North, Film Composer. Jefferson, NC: McFarland \& Company, Inc., Publishers.

Jackson, Naomi. 2000. Converging Movements: Dance and Jewish Culture at the $92^{\text {nd }}$ Street Y. Hanover and London: Wesleyan University Press/University Press of New England.

-


Jacobson, Matthew Frye. 1998. Whiteness of a Different Color: European Immigrants and the Alchemy of Race. Cambridge, MA: Harvard University Press.

Jowitt, Deborah. 1988. Time and the Dancing Image. Berkeley and Los Angeles: University of California Press.

Krackman, Herb. 1937. “Seeing America First: IV_-Miner's Homecoming.” New Masses, February 2, 7. OSU BICL\&M.

Kriegsman, Sali Ann. 1981. Modern Dance in America: The Bennington Years. Boston: G. K. Hall \& Co. Lloyd, Margaret. 1942. "Dance Is for People, Part II.” No source, May 16. Anna Sokolow Clippings, JRDD, NYPL.

Lyle, Cynthia. 1979. Dancers on Dancing. New York: Sterling Publishing Co.

Mackenzie, Aza Bard. 1987. Interview by Larry Warren. March 21. Transcript. Larry Warren Collection.

Manning, Susan. 1993. Ecstasy and the Demon: Feminism and Nationalism in the Dances of Mary Wigman. Berkeley, Los Angeles, and London: University of California Press.

—. 2004. Modern Dance, Negro Dance: Race in Motion. Minneapolis: University of Minnesota Press.

—. 2007. "Ausdruckstanz Across the Atlantic." In Dance Discourses: Keywords in Dance Research, edited by Susanne Franco and Marina Nordera, 46-60. London and New York: Routledge.

Martin, John. 1935a. "New Dance League Holds 3D Festival: Park Theatre is Crowded for Performances in Evening and Afternoon." New York Times, June 10, n.p. Dance Clippings, New Dance League Folder, HTC.

—. 1935b. "The Dance: With Words." New York Times, June 30, 4X.

. 1935c. "Throng is Stirred by Dance Recital: Audience Filling Carnegie Hall Gives Ovations to

Artists on Long Program." New York Times, December 16, 23. Proquest Historical Newspapers (accessed August 16, 2012).

- 1936. America Dancing: The Background and Personalities of the Modern Dance. New York: Dodge Publishing Company.

- 1937. "New Recital Given by Martha Graham: Dancer and Her Group Present Program of Wide Variety at Guild Theatre." New York Times, March 15, 16. Proquest Historical Newspapers (accessed August 16, 2012).

Martin, Randy. 1998. Critical Moves: Dance Studies in Theory and Politics. Durham: Duke University Press.

McCausland, Elizabeth. 1937. "Sokolow Accents Contemporary Mood: Young Dancer Interests New York Audience Present at Her First Program Last Sunday." Springfield (Massachusetts) Morning Union, November 21, n.p. Anna Sokolow Clippings, JRDD, NYPL.

"Minor at Lenin Rally in Hartford." 1943. Daily Worker, February 3, 4.

Mitchell, Louise. 1937. "New Dance Unit Is Tops.” Daily Worker, March 3, n.p. Anna Sokolow Clippings, JRDD, NYPL.

Morrison, Rose. 1938. "Review of Broadway Stage." New Voices, October, 6. The Microforms Section of The New York Public Library (hereafter Microforms, NYPL).

New Dance League June Dance Festival. 1935. Program, June 9. Workers Dance League Programs, JRDD, NYPL.

New Dance: Special Recital Issue. 1935. January, 6. Workers Dance League Programs, JRDD, NYPL. Ocko, Edna. 1934. "The Revolutionary Dance Movement." New Masses, June 12, 27-28. OSU BICL\&M.

—. 1935. "Martha Graham's 'Panorama." New Theatre, September, 27.

. 1936a. "Dancers, Take a Bow." New Theatre, February, 24-25.

—. 1936b. "The Dance Congress." New Theatre, July, 23.

Oja, Carol T. 1988. "Composer with a Conscience: Elie Seigmeister in Profile." American Music 6 (2): 158-180. JSTOR (accessed October 16, 2011).

La Paloma Azul. 1940. Program, September 20. Item GP-DF00163, Centro Nacional de Investigación, Documentación y Información de la Danza, Biblioteca de las Artes, Centro Nacional de las Artes, Mexico City. 
Phelan, Peggy. 1993. Unmarked: The Politics of Performance. London and New York: Routledge. Prickett, Stacey. 1990. “Dance and the Workers' Struggle.” Dance Research: The Journal of the Society for Dance Research 8 (1): 47-61.

- 1994. "The People': Issues of Identity within the Revolutionary Dance." Studies in Dance History V (1), "Of, By, and For the People: Dancing on the Left in the 1930s," edited by Lynn Garafola: 14-22.

Rochfort, Desmond. 2006. "The Sickle, the Serpent, and the Soil: History, Revolution, Nationhood, and Modernity in the Murals of Diego Rivera, José Clemente Orozco, and David Alfaro Siquerios." In The Eagle and the Virgin: Nation and Cultural Revolution in Mexico, 1920-1940, edited by Mary Kay Vaughan and Stephen E. Lewis, 43-57. Durham: Duke University Press.

Rossen, Rebecca. 2011. "Hasidic Drag: Jewishness and Transvestism in the Modern Dances of Pauline Koner and Hadassah." Feminist Studies 37 (2): 334-364. Religion and Philosophy Collection, EBSCO (accessed December 12, 2011).

Rudhyar, Dane. 1936. “Art and Propaganda.” Dance Observer, December, 109, 113.

Siqueiros, David Alfaro. 1934. "Rivera’s Counter-Revolutionary Road.” New Masses, May 29, 16-19. OSU BICL\&M.

Sorell, Walter. 1964. "We Work Toward Freedom.” Dance Magazine, January, 52-53, 73.

"Talking to Dance and Dancers: Anna Sokolow." 1967. Dance and Dancers, July, 18-19.

Toledano, Vincente Lombardo. 1936. "Greeting from Mexico." New Masses, May 5, 14. OSU BICL\&M.

- 1937. "Trotsky in Mexico.” New Masses, February 2, 6-7. OSU BICL\&M.

Tomko, Linda. 1999. Dancing Class: Gender, Ethnicity, and Social Divides in American Dance, 1890 1920. Bloomington and Indianapolis: Indiana University Press.

Tortajada Quiroz, Margarita. 2001. Frutos de Mujer: La Mujeres en la Danza Escénia. México: Teoría y Práctica de Arte.

U.S. Congress. House. Committee on Un-American Activities. 1951. Report on the Communist "Peace" Offensive: A Campaign to Disarm and Defeat the United States. $82^{\text {nd }}$ Cong., $1^{\text {st }}$ sess., April 25. LexisNexis Congressional (accessed October 13, 2009).

U.S. Department of State. FOIPA No. 1138496-000. Sokolow, Anna. Obtained under Freedom of Information Privacy Act Exemptions (5 USC 522; 5 USC 522a).

Warren, Larry. 1991. Anna Sokolow: The Rebellious Spirit. Princeton, NJ: Princeton Book Company, Publishers.

Wedger, Charles. 1935. "Toward the Mexican Crisis: Millions of Peons-Millionaire Rulers-An Explosion Preparing." New Masses, September 3, 11-14. OSU BICL\&M.

Weisser, Irving. 1935. "Face to Face with Michael Gold: An Interview." New Voices, August, 9-10. Microforms, NYPL.

Workers Dance League Presents for Benefit of "Daily Worker" Recital_Leading Revolutionary Dance Groups. 1934. Program, January 7. Workers Dance League Programs, JRDD, NYPL. 


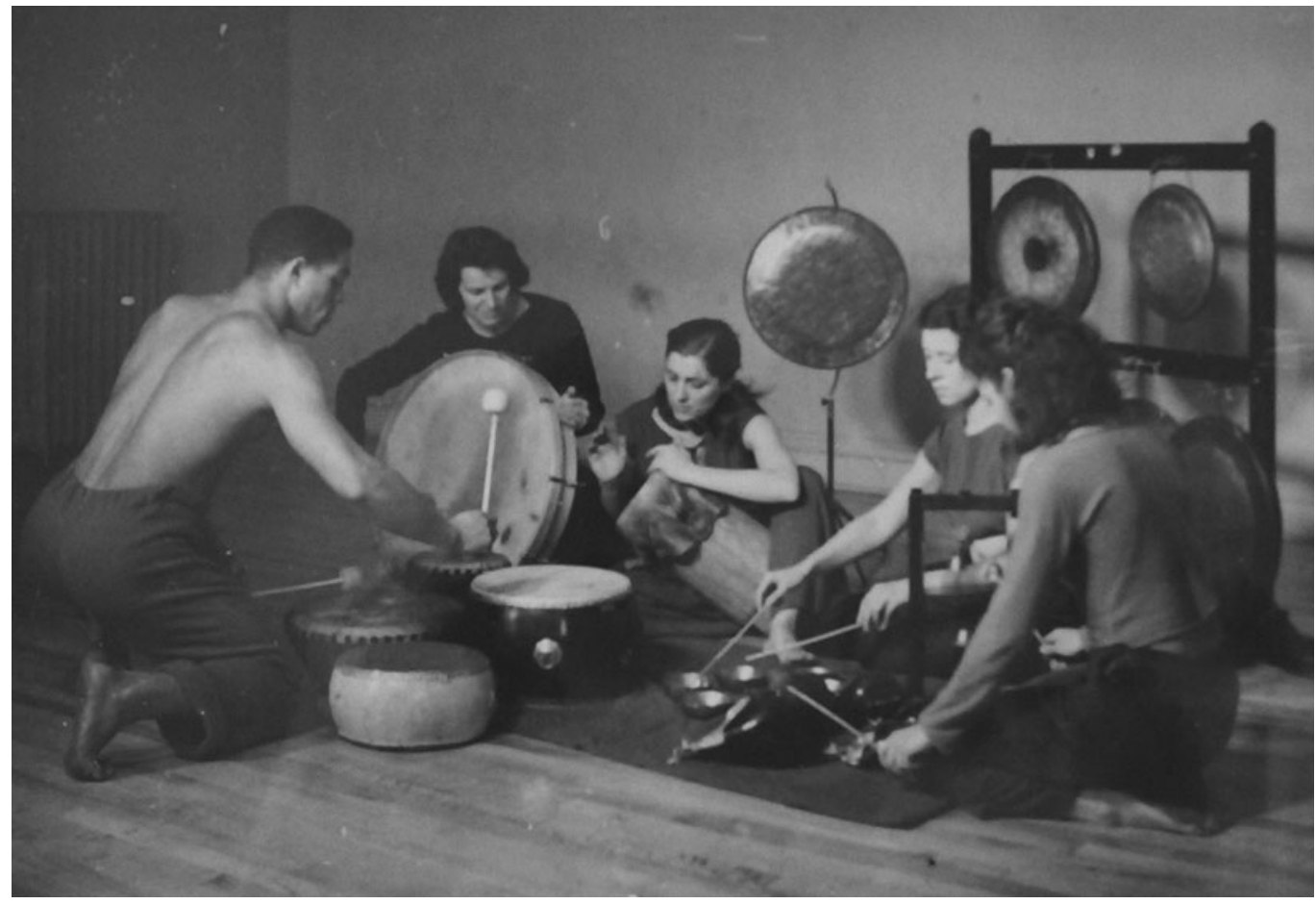

